\title{
Seasonal and Spatial Variations in Water Physicochemical Quality of Coastal Potou Lagoon (Côte d'Ivoire, Western Africa)
}

\author{
Yéo Kandana Marthe1, Goné Droh Lanciné1*, Kamagaté Bamory1, \\ Douagui Gountoh Aristide1, Dembélé Ardjouma² \\ ${ }^{1}$ Laboratory of Geosciences and Environment, University Nangui Abrogoua, Abidjan, Côte d'Ivoire \\ ${ }^{2}$ Laboratory of Agricultural Development, University Nangui Abrogoua, Abidjan, Côte d'Ivoire \\ Email: *dialou259@yahoo.fr
}

Received 25 May 2015; accepted 11 July 2015; published 14 July 2015

Copyright (C) 2015 by authors and Scientific Research Publishing Inc.

This work is licensed under the Creative Commons Attribution International License (CC BY). http://creativecommons.org/licenses/by/4.0/

c) (i) Open Access

\section{Abstract}

The study investigates the seasonal and spatial variations in water quality parameters at four different locations along Potou lagoon for seventeen consecutive months. In order to explore spatial variation among different stations and seasonal changes, no parametric test of ANOVA was used to compare the mean values of the tested parameters for all the different sampling sites and seasons. Seasonal observations on water quality parameters and chlorophyll- $a$ in Potou coastal lagoon revealed that the coastal water was significantly influenced by freshwater during the long and short rainy seasons. The seasonal significant variation $(p<0.05)$ was generally recorded between the long dry season and the short rainy season. Temperature, salinity, $\mathrm{pH}$, dissolved oxygen, transparency and chlorophyll- $a$ increased during the long dry season, whereas, the concentration of nutrients (nitrite, nitrate, ammonium and soluble reactive phosphorus) increased in the rainy periods. Contrary to the seasonal variation, a spatial homogeneity (horizontal) was registered for all variables, a condition related to the low human occupation in the lagoon watershed. Comparing this study with others conducted in Potou lagoon in 2008, no critical differences that evidence alteration in the water quality were found.

\section{Keywords}

Potou Lagoon, Water, Quality and Variation

\footnotetext{
${ }^{*}$ Corresponding author.
} 


\section{Introduction}

Worldwide deterioration of surface water (lagoon, river...) quality has been attributed to both natural processes and anthropogenic activities, including hydrological features, climate change, precipitation, agricultural land use, and sewage discharge [1] [2]. Coastal lagoon pollution is one of the serious problems retarding coastal development [3]. These ecosystems occupy around $13 \%$ of the coastal areas worldwide [4] and are important contributors to groundwater reservoirs, local and regional weather stability, preservation of biodiversity and also as water suppliers [5]. In spite of their importance and multiple uses, urban development and the intense human use of coastal lagoons and their surroundings often have led to water contamination, eutrophication, introduction of invasive species, and habitat destruction [6]-[9]. Better understanding of coastal lagoons characteristics and potential impacts allows policy makers and lagoons users to derive and implement policies, legislation and management practices leading to suitable use of coastal lagoons resources for economic gains while preserving their biodiversity. Such interventions require improved knowledge on the processes influencing the physical, chemical and biological characteristics of the lagoons and ongoing changes due to land use practices in the proximity of sensitive lagoons [10].

The two lagoons, Potou and Adjin, located in Abidjan District, communicate through a natural channel. Potou lagoon is an important source of allieutics resources for local communities and the city of Abidjan in addition to its operating contemplated drinking water. It is used also for recreational purposes and washes. The quality concerns about this lagoon stem from the population pressures in its catchment. Indeed, Potou lagoon receives several types of inputs, viz., urban, industrial and agricultural wastes. Several studies [11]-[13] have demonstrated that these wastes result in significant alteration in the water quality.

In this paper, spatial and seasonal change of physicochemical and biological parameters has been evaluated in response to the stress caused by anthropogenic inputs from land use changes, agriculture, and industries. The results and conclusion drawn thereon would be useful for future management practices of the lagoon environment.

\section{Material and Methods}

\subsection{Study Area}

Potou lagoon is located between latitudes $5^{\circ} 32^{\prime} \mathrm{N}-5^{\circ} 36^{\prime} \mathrm{N}$ and longitude $3^{\circ} 81^{\prime} \mathrm{E}-3^{\circ} 76^{\prime} \mathrm{E}$ and covers a surface area of $22.8 \mathrm{Km}^{2}$. It is characterized by depths generally less than $3 \mathrm{~m}$, but reach $20 \mathrm{~m}$ at the outlet of Mé river [14] [15]. Potou lagoon is separated from the Ebrié lagoon system by a narrow channel in the south of the Potou lagoon (Figure 1). The climate is close to equatorial, with an annual rainfall ranging from 1500 to $2000 \mathrm{~mm}$.

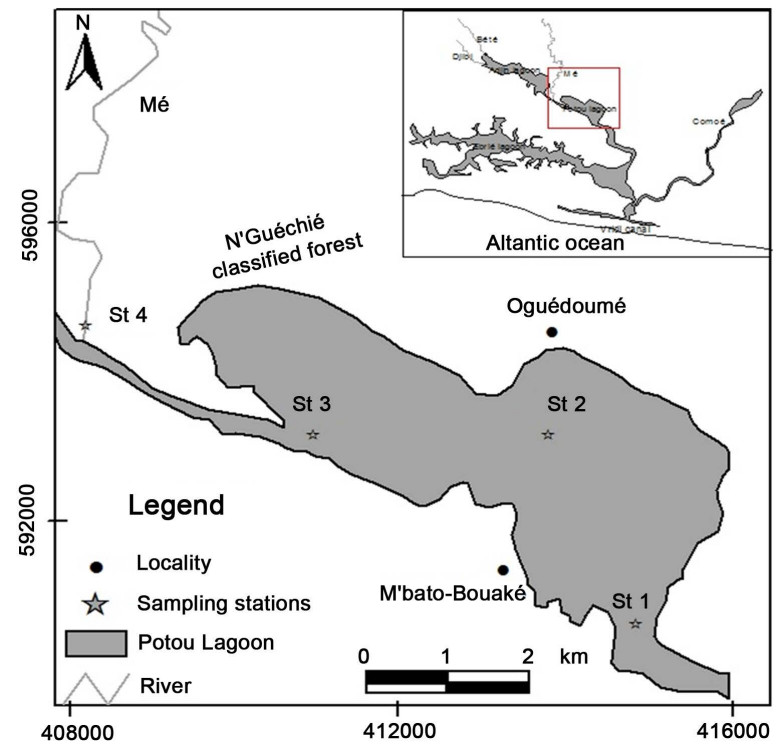

Figure 1. Potou lagoon showing location of sampling stations. 
Lagoon seasons are resulting for continental seasons. It includes two rainy seasons separated by two dry seasons. The long rainy season (LRS) from April to July is followed by the short dry season (SDS) in August. The short rainy season (SRS) is from September to November, while the long dry season (LDS) is from December to Mars. Potou lagoon receives freshwater from Mé river in the north and those of the Comoé river in the south [14]. Agriculture is the main human activity in the lagoon area and its watershed. Coconut, oil palm, banana and hevea plantations cover most of the arable land. Vegetable crops grown along the waters of the lagoon with use fertilizers enriched waters by nitrogen and phosphorus nutrients. The lagoon water serves the surrounding rural settlements for domestic purposes, irrigation, herd watering and recreation. In addition, the lagoon receives waste water coming from villages situated around the lagoon. All these anthropogenic pressures acting directly or indirectly on the water contribute to the degradation of the quality of lagoon waters [14] [16] [17].

\subsection{Water Sampling and Analysis}

Water of Potou lagoon was sampled monthly from 4 locations (Figure 1) during 17 months (February 2012 to January 2013 and during February, April, June, August, and November 2013). The sites were selected based on a number of factors including geographical location, anthropogenic activities and access. A detailed description of the sites is shown in Table 1.

Samples were taken with a Niskin bottle at the depth of $0.5 \mathrm{~m}$ below the surface and were collected in polyethylene bottles. Once collected, all samples were stored on ice and immediately transported to the laboratory. A total of nine physicochemical parameters for water quality control and pollution studies were evaluated in this study. Temperature, $\mathrm{pH}$ and dissolved oxygen (DO) were measured in situ using the HI $9828 \mathrm{pH} / \mathrm{ORP} / \mathrm{EC} / \mathrm{DO}$ multiparameter brand HANNA. Water transparency was also determined in situ using a Secchi disc. Nitrate, nitrite, ammonium and phosphate were estimated by following standard methods (AFNOR standards ISO 7890-3; ISO 6777; T 90015; T 90023 respectively) after filtering the water samples through GF/C whatman filter paper $(0.45 \mu \mathrm{m})$. Chlorophyll- $a(\mathrm{Chl}-a)$ was analyzed by spectrophotometric method according to Lorenzen [18]. For all the spectrophotometric analyses, a double beam UV-Visible Spectrophotometer (SHIMADZU UV/visible1700 pharma) was used.

For statistical analysis, no parametric test of ANOVA (Software Statistica 7.1) was used to compare the mean values of the tested parameters for all the different sampling sites and seasons. The coefficient of correlation amongst the physicochemical parameters was calculated by the spearman correlations test.

\section{Results and Discussion}

Physicochemical quality assessment of surface bodies may widely reflect the pollution load and anthropogenic pressure on surface water systems. Table 2 compares the mean values of physicochemical water quality parameters for the four sampling sites on Potou lagoon for the 17 months study period to reveal spatial variation. Table 3 shows the seasonal variations and Table 4 shows the correlation coefficients of physicochemical water quality parameters.

\subsection{Spatial Variation in Water Quality Parameters}

No horizontal significant differences (Table 2) were found in Potou lagoon during the sampled period for all the parameters measured $(p<0.05)$. Low human occupation and densely vegetated areas in the lagoon watershed as well as the small surface area are contributing factors to the lagoon's homogeneity, since the water quality of

Table 1. Description of the sampling sites.

\begin{tabular}{ccc}
\hline Sampling sites & coordinates & Description \\
\hline Site 1 & $\mathrm{X}=414866$ & confluence of the Potou lagoon with the channel connecting \\
& $\mathrm{Y}=590627$ & Potou lagoon to Ebrié Lagoon (downstream Potou) \\
Site 2 & $\mathrm{X}=413809$ & Eastern of Potou lagoon, it receives wastewater from Oguédoumé village \\
& $\mathrm{Y}=593171$ & Upstream of Potou lagoon \\
Site 3 & $\mathrm{X}=410953$ & On the river Mé at 100 $\mathrm{m}$ from the confluence of the \\
& $\mathrm{Y}=593170$ & Mé and channel linking Adjin and Potou lagoons \\
\hline
\end{tabular}


Table 2. Spatial variations in physicochemical characteristics of Potou lagoon.

\begin{tabular}{|c|c|c|c|c|c|c|c|c|c|c|}
\hline $\begin{array}{c}\text { Sampling } \\
\text { site }\end{array}$ & $\begin{array}{c}\text { Statistical } \\
\text { parameters }\end{array}$ & $\begin{array}{c}\text { Transp } \\
\text { (m) }\end{array}$ & $\mathrm{T}\left({ }^{\circ} \mathrm{C}\right)$ & $\mathrm{pH}$ & $\begin{array}{c}\mathrm{DO} \\
\left(\mathrm{mg} \cdot \mathrm{L}^{-1}\right)\end{array}$ & $\begin{array}{c}\text { Chl-a } \\
\left(\mu \mathrm{g} \cdot \mathrm{L}^{-1}\right)\end{array}$ & $\begin{array}{c}\mathrm{NO}_{2}^{-} \\
\left(\mu \mathrm{g} \cdot \mathrm{L}^{-1}\right)\end{array}$ & $\begin{array}{c}\mathrm{NO}_{3}^{-} \\
\left(\mathrm{mg} \cdot \mathrm{L}^{-1}\right)\end{array}$ & $\begin{array}{c}\mathrm{PO}_{4}^{3-} \\
\left(\mu \mathrm{g} \cdot \mathrm{L}^{-1}\right)\end{array}$ & $\begin{array}{c}\mathrm{NH}_{4}^{+} \\
\left(\mathrm{mg} \cdot \mathrm{L}^{-1}\right)\end{array}$ \\
\hline \multirow{2}{*}{ St 1} & Mean \pm SD & $0.39^{\mathrm{a}} \pm 0.15$ & $29.33^{\mathrm{a}} \pm 1.96$ & $6.81^{a} \pm 0.52$ & $5.95^{\mathrm{a}} \pm 1.17$ & $14.85^{\mathrm{a}} \pm 5.56$ & $4.03^{\mathrm{a}} \pm 0.98$ & $3.14^{\mathrm{a}} \pm 1.75$ & $68.59^{\mathrm{a}} \pm 25.99$ & $0.06^{\mathrm{a}} \pm 0.04$ \\
\hline & Range & $0.10-0.60$ & $26.30-33.50$ & $5.58-7.56$ & $3.97-8.13$ & $5.13-23.94$ & $2.00-6.00$ & $0.46-7.06$ & $20.00-112.00$ & $0.01-0.12$ \\
\hline \multirow{2}{*}{ St 2} & Mean \pm SD & $0.37^{\mathrm{a}} \pm 0.13$ & $29.06^{\mathrm{a}} \pm 1.92$ & $6.86^{a} \pm 0.52$ & $5.73^{\mathrm{a}} \pm 1.40$ & $17.91^{\mathrm{a}} \pm 7.82$ & $3.32^{\mathrm{a}} \pm 1.46$ & $3.08^{\mathrm{a}} \pm 2.01$ & $53.42^{\mathrm{a}} \pm 27.34$ & $0.06^{\mathrm{a}} \pm 0.04$ \\
\hline & Range & $0.10-0.50$ & $26.40-33.20$ & $5.76-7.80$ & $3.49-8.10$ & $6.08-34.27$ & $1.00-6.00$ & $0.50-7.14$ & $10.00-113.00$ & $0.01-0.16$ \\
\hline \multirow{2}{*}{ St 3} & Mean \pm SD & $0.37^{\mathrm{a}} \pm 0.14$ & $28.69^{\mathrm{a}} \pm 1.86$ & $6.68^{\mathrm{a}} \pm 0.54$ & $5.16^{\mathrm{a}} \pm 1.49$ & $19.15^{\mathrm{a}} \pm 9.21$ & $3.78^{\mathrm{a}} \pm 1.22$ & $3.08^{\mathrm{a}} \pm 1.65$ & $56.71^{\mathrm{a}} \pm 31.27$ & $0.07^{\mathrm{a}} \pm 0.04$ \\
\hline & Range & $0.10-0.50$ & $26.60-33.00$ & $5.20-7.41$ & $2.34-8.91$ & $8.00-40.95$ & $1.00-6.00$ & $0.17-5.21$ & $5.30-117.90$ & $0.01-0.15$ \\
\hline \multirow{2}{*}{ St 4} & Mean \pm SD & $0.40^{\mathrm{a}} \pm 0.15$ & $27.64^{\mathrm{a}} \pm 1$ & $6.66^{a} \pm 0.40$ & $5.35^{\mathrm{a}} \pm 1.47$ & $24.89^{\mathrm{a}} \pm 16.56$ & $3.67^{\mathrm{a}} \pm 2.01$ & $2.85^{\mathrm{a}} \pm 1.83$ & $72.94^{\mathrm{a}} \pm 44$ & $0.06^{\mathrm{a}} \pm 0.04$ \\
\hline & Range & $0.20-0.52$ & $25.19-31.00$ & $5.89-7.37$ & $2.95-8.48$ & $5.32-57.43$ & $0.60-7.00$ & $0.41-7.05$ & $13.00-195.00$ & $0.00-0.13$ \\
\hline
\end{tabular}

For each parameter and site mean values with different lowercase letters (superscripts) are significantly different $(p<0.05)$; SD: standard deviation, Transp: transparency, T: temperature, Chl-a: chlorophyll- $a$, DO: dissolved oxygen.

Table 3. Seasonal variations in physicochemical characteristics of Potou lagoon.

\begin{tabular}{|c|c|c|c|c|c|c|c|c|c|c|}
\hline ante & & & & $\mathrm{pH}$ & $-1)$ & & $\begin{array}{c}\mathrm{NO}_{2}^{-} \\
\left(\mu \mathrm{g} \cdot \mathrm{L}^{-1}\right)\end{array}$ & $\begin{array}{c}\mathrm{NO}_{3}^{-} \\
\left(\mathrm{mg} \cdot \mathrm{L}^{-1}\right)\end{array}$ & $\begin{array}{c}\mathrm{PO}_{4}^{3-} \\
\left(\mu \mathrm{g} \cdot \mathrm{L}^{-1}\right)\end{array}$ & $\begin{array}{c}\mathrm{NH}_{4}^{+} \\
\left(\mathrm{mg} \cdot \mathrm{L}^{-1}\right)\end{array}$ \\
\hline \multirow{4}{*}{ Site 1} & DS & $54^{\mathrm{a}}+$ & & $16^{\mathrm{a}} \pm 0.51$ & $6.68^{\mathrm{a}} \pm$ & $9.49^{\mathrm{a}} \pm 3.79$ & $60^{\mathrm{a}} \pm 0.55$ & $.61^{\mathrm{a}} \pm 1.43$ & $.80^{\mathrm{a}} \pm 13.10$ & \\
\hline & RS & & & & $5.53^{\mathrm{a}}=$ & & & & $77.77^{\mathrm{ab}} \pm 20.83$ & \\
\hline & $S$ & $0.44^{\mathrm{ab}} \pm 0.08$ & $.35^{\mathrm{a}} \pm 0.49$ & $50^{\mathrm{a}} \pm 0.39$ & $78^{\mathrm{a}} \pm 1.17$ & $15.03^{\mathrm{ab}} \pm 5.31$ & $.00^{\mathrm{a}} \pm 0.00$ & $55^{\mathrm{a}}+015$ & $9.00^{\mathrm{ab}} \pm 14.14$ & $.06^{\mathrm{a}} \pm 0 . \mathrm{C}$ \\
\hline & SRS & $23^{b} \pm 0.10$ & $3.79^{\mathrm{a}} \pm 0.24$ & $48^{\mathrm{a}} \pm$ & $5.24^{\mathrm{a}} \pm 1.11$ & $8.84^{\mathrm{b}} \pm 4.73$ & $4.63^{\mathrm{a}} \pm 1.11$ & .57 & $4^{b} \pm 14.67$ & 0.05 \\
\hline & LDS & .09 & $.45^{\mathrm{a}} \pm 1.60$ & $26^{\mathrm{a}} \pm 0.43$ & $6.58^{\mathrm{a}} \pm 1.68$ & $25.85^{\mathrm{a}} \pm 7.99$ & $2.4^{\mathrm{a}} \pm 1.52$ & $1.28^{\mathrm{a}} \pm 0.90$ & $27.89^{\mathrm{a}} \pm 17.09$ & \\
\hline & S & & $.01^{\mathrm{a}} \pm 2.34$ & $79^{\mathrm{a}} \pm 0.52$ & $5.39^{\mathrm{a}} \pm 1.45$ & $16.70^{\mathrm{ab}} \pm 3.83$ & $4.17^{\mathrm{a}} \pm 1.17$ & $4.29^{\mathrm{b}} \pm 2.18$ & $7.10^{\mathrm{a}} \pm 31.96$ & $.07^{\mathrm{a}} \pm 0$. \\
\hline & SDS & $0.43^{\mathrm{ab}} \pm 0.11$ & $6.82^{\mathrm{a}} \pm 0.45$ & $.71^{\mathrm{a}} \pm 0.18$ & $5.96^{\mathrm{a}} \pm 1.17$ & $18.39^{\mathrm{ab}} \pm 1.82$ & $3.5^{\mathrm{a}} \pm 2.12$ & $3.41^{\mathrm{ab}} \pm 2.25$ & $67.50^{\mathrm{a}} \pm 13.44$ & $0.08^{\mathrm{a}} \pm 0.1 \mathrm{c}$ \\
\hline & SRS & $23^{\mathrm{b}} \pm 0$ & $.53^{\mathrm{a}} \pm 0.19$ & $.54^{\mathrm{a}} \pm 0.54$ & & & 1.28 & $3.37^{\mathrm{ab}} \pm 1.52$ & $72.80^{\mathrm{a}} \pm 9.34$ & 0.07 \\
\hline \multirow{4}{*}{ te } & LDS & $0.49^{\mathrm{a}} \pm 0.09$ & $9.64^{\mathrm{a}} \pm 1.91$ & $7.11^{\mathrm{a}} \pm 0.44$ & $6.34^{\mathrm{a}} \pm 1.71$ & $26.45^{\mathrm{a}} \pm 9.85$ & $2.60^{\mathrm{a}} \pm 1.14$ & $1.04^{\mathrm{a}} \pm 1.05$ & $21.30^{\mathrm{a}} \pm 13.89$ & $0.02^{\mathrm{a}} \pm 0$. \\
\hline & ; & $0.35^{\mathrm{ab}} \pm 0.11$ & $8.99^{\mathrm{a}} \pm 2.29$ & $6.55^{\mathrm{a}} \pm 0.31$ & $4.51^{\mathrm{a}} \pm 0.82$ & $18.06^{\mathrm{ab}} \pm 6.50$ & $3.83^{\mathrm{ab}} \pm 0.75$ & $3.95^{\mathrm{b}} \pm 1.21$ & $75.27^{\mathrm{b}} \pm 24.96$ & $0.09^{\mathrm{b}} \pm 0.0$ \\
\hline & SDS & $0.45^{\mathrm{ab}} \pm$ & $26.70^{\mathrm{a}} \pm 0.01$ & $.81^{\mathrm{a}} \pm 0.18$ & $6.00^{\mathrm{a}} \pm 0.62$ & $22.96^{\mathrm{ab}} \pm 8.29$ & $4.00^{\mathrm{ab}} \pm$ & $3.66^{\mathrm{ab}}=$ & $45.50^{\mathrm{ab}} \pm 21.92$ & $0.10^{\mathrm{ab}} \pm 0.0$ \\
\hline & SRS & $20^{\mathrm{b}} \pm 0.08$ & $8.04^{\mathrm{a}} \pm 0.15$ & $29^{a} \pm 0.75$ & $4.23^{\mathrm{a}} \pm 1.39$ & $9.76^{b} \pm 3.33$ & $5.08^{b} \pm 0.83$ & $4.04^{\mathrm{ab}} \pm 0.66$ & $78.72^{\mathrm{b}} \pm 15.83$ & $0.08^{\mathrm{ab}} \pm 0$ \\
\hline \multirow{4}{*}{ Site 4} & LDS & $0.55^{\mathrm{a}} \pm 0.14$ & $28.98^{\mathrm{a}} \pm 1.66$ & $7.01^{\mathrm{a}} \pm 0.30$ & $6.94^{\mathrm{a}} \pm 1.35$ & $36.82^{\mathrm{a}} \pm 17.56$ & $4.80^{\mathrm{a}} \pm 2.28$ & $1.34^{\mathrm{a}} \pm 0.98$ & $28.02^{\mathrm{a}} \pm 14.93$ & $0.01^{\mathrm{a}} \pm 0 . \mathrm{C}$ \\
\hline & RS & $0.38^{\mathrm{ab}} \pm 0.11$ & $7.92^{\mathrm{a}} \pm 2.40$ & $.48^{a} \pm 0.39$ & $5.00^{\mathrm{ab}} \pm 0.72$ & $25.50^{\mathrm{ab}} \pm 4.53$ & $3.43^{\mathrm{a}} \pm 1.77$ & $3.39^{\mathrm{a}} \pm 2.09$ & $105.10^{\mathrm{b}} \pm 50.11$ & $0.07^{\mathrm{a}} \pm 0 . \mathrm{C}$ \\
\hline & SDS & $0.38^{\mathrm{ab}} \pm 0.04$ & $26.55^{\mathrm{a}} \pm 0.08$ & $6.49^{\mathrm{a}} \pm 0.40$ & $4.93^{\mathrm{ab}} \pm 0.11$ & $28.79^{\mathrm{ab}} \pm 8.65$ & $4.00^{\mathrm{a}} \pm 0.00$ & $2.52^{\mathrm{a}} \pm 0.07$ & $57.50^{\mathrm{ab}} \pm 17.68$ & $0.10^{\mathrm{a}} \pm 0.0$ \\
\hline & 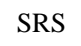 & 0.25 & $08^{\mathrm{a}} \pm$ & $.57^{\mathrm{a}} \pm$ & & $7.07^{\mathrm{b}} \pm 1.93$ & $2.45^{\mathrm{a}} \pm 2.28$ & $4.09^{\mathrm{a}} \pm 1.65$ & $88.57^{\mathrm{ab}} \pm 6.23$ & $0.07^{\mathrm{a}} \pm 0$. \\
\hline
\end{tabular}

Table 4. Correlation matrix (Pearson) of physicochemical water quality parameters of Potou lagoon.

\begin{tabular}{cccccccccc}
\hline & Transp & $\mathrm{Temp}$ & $\mathrm{pH}$ & $\mathrm{DO}$ & $\mathrm{NH}_{4}^{+}$ & $\mathrm{NO}_{2}^{-}$ & $\mathrm{NO}_{3}^{-}$ & $\mathrm{PO}_{4}^{3-}$ & $\mathrm{Chl}-a$ \\
\hline $\mathrm{Transp}$ & 1 & $0.482^{* *}$ & $0.434^{* *}$ & $0.453^{* *}$ & $-0.648^{* *}$ & $-0.285^{*}$ & $-0.734^{* *}$ & $-0.715^{* *}$ & $0.774^{* *}$ \\
$\mathrm{Temp}$ & - & 1 & $0.342^{* *}$ & $0.249^{*}$ & $0.417^{* *}$ & $-0.285^{*}$ & $-0.458^{* *}$ & $-0.529^{* *}$ & $0.372^{* *}$ \\
$\mathrm{pH}$ & - & - & 1 & $0.462^{*}$ & $-0.488^{* *}$ & -0.229 & $-0.470^{* *}$ & $-0.483^{* *}$ & $0.280^{*}$ \\
$\mathrm{OD}$ & - & - & - & 1 & $-0.432^{* *}$ & 0.062 & $-0.381^{* *}$ & $-0.409^{* *}$ & $0.442^{* *}$ \\
$\mathrm{NH}_{4}{ }^{+}$ & - & - & - & - & 1 & $0.338^{* *}$ & $0.682^{* *}$ & $0.705^{* *}$ & $-0.587^{* *}$ \\
$\mathrm{NO}_{2}^{-}$ & - & - & - & - & - & 1 & $0.407^{* *}$ & $0.243^{*}$ & -0.161 \\
$\mathrm{NO}_{3}^{-}$ & - & - & - & - & - & - & 1 & $0.672^{* *}$ & $-0.636^{* *}$ \\
$\mathrm{PO}_{4}{ }^{-}$ & - & - & - & - & - & - & - & 1 & $-0.624^{* *}$ \\
$\mathrm{CHL}_{-}^{-} a$ & - & - & - & - & - & - & - & - & 1 \\
\hline
\end{tabular}

Transp: transparency, T; temperature, Chl- $a$ : chlorophyll- $a$, DO: dissolved oxygen; Items in bold indicate significant correlations: ${ }^{*} p=0.05$ (correlation is significant; two-tailed); ${ }^{* *} p=0.01$ (correlation is significant; two-tailed). 
lagoons may vary depending on the geological morphology, vegetation, and activities in the catchment basin [19].

Hydrodynamic processes are also affected by the morphometry of the water body [20], especially by its size, by the topography of the bottom and by the mean depth [21]. In this sense, water bodies with small surface areas and not very deep water columns commonly present horizontal homogeneity as we found for Potou lagoon [22]. Some authors studying coastal lagoons in Brazil also found that the low deep water column, the low human occupation and densely vegetated areas in the lagoon watershed as well as the small surface area are also as the mains factors determining the water circulation and characterizing the lagoons of homogeneity environments [3] [23]-[25].

\subsection{Seasonal Variation of Water Quality Parameters}

Seasonal variation of the in situ measured physicochemical and biological parameters were recorded in Table 3. Transparency of the water column varied relatively little, between 0.1 and $0.80 \mathrm{~m}$ obtained respectively during October and February. Low transparency of the water column seems to be a common feature for several coastal lagoons such as Comprida lagoon in Brazil [23] and Ebrié lagoon in Cote d'Ivoire [26]. The transparency value (range, $0.20 \pm 0.08-0.25 \pm 0.04 \mathrm{~m}$ ) recorded in the short rainy season was significantly lower $(p<0.05)$ than the mean values for the long dry season indicating that suspended particulate matter contribute to decrease water transparency [27].

Water temperature ranged between $25.19^{\circ} \mathrm{C}$ and $33.50^{\circ} \mathrm{C}$ and varied in accordance with the equatorial climate along the years (Table 2). No significant variation in temperature values was observed among the four seasons. These results suggest that water temperature in this study area was not determined by season. A principal component analysis (PCA) also demonstrates that water temperature is an important factor influencing the variation of the water chemical parameters (Table 3) because it has a significant correlation with most of these parameters.

Our study found $\mathrm{pH}$ values ranging from 5.20 to 7.90, which shows that Potou lagoon presents water $\mathrm{pH}$ near to neutral most of the time, with periods of slightly acidity. These values showed no significant seasonal variation during the sampling period. However, the highest mean values $(\mathrm{pH} 7.01 \pm 0.30-7.26 \pm 0.43$ ) were recorded in the long dry season. $\mathrm{pH}$ had positive correlations (Table 4) with water temperature $(\mathrm{R}=0.342, p<0.01)$, DO $(\mathrm{R}=0.462, p<0.05)$, and Chl- $a(\mathrm{R}=0.280, p<0.05)$, what may be explained by the fact that higher primary production rates consume $\mathrm{CO}_{2}$, which leads to higher $\mathrm{pH}$ values, and increase $\mathrm{DO}$ in the water. Coastal lagoons usually present higher $\mathrm{pH}$ values especially because of the sea water influence [7] [28]-[31]. The presence of humic materials, on the other hand, can acidify the waters [23]. The mean values recorded by [22] in the same lagoon are also in the same range ( 0 - 5).

Dissolved oxygen concentrations showed a positive correlation $(\mathrm{R}=0.249)$ with temperature, what was expected since higher temperatures increase the oxygen solubility in the water. Unlike sites 1,2 and 3 which showed no seasonal variation, the mean value of DO at site 4 was significantly higher $(p<0.05)$ in the long dry season than the value recorded in short rainy season. The decrease in $\mathrm{DO}$ concentrations and $\mathrm{pH}$ values during the short rainy season can be a result of a reduction in primary production and increase of organism community respiration in the water column. DO values ranged from 2.34 to $8.91 \mathrm{mg} \cdot \mathrm{L}^{-1}$ and oxygen saturation remained around $80 \%$ during most of the sampled period, which demonstrates that oxygen is not a limiting factor for the biota in Potou lagoon. Similar oxygen concentrations are found in other coastal lagoons, such as Comprida lagoon in South East Brazil [23], Foz de Almargem lagoon in Portugal [29] and Icarai and Guanabara lagoons in South East Brazil [32].

Potou lagoon presented high Chl- $a$ values ranging between 5.13 and $57.43 \mu \mathrm{g} \cdot \mathrm{L}^{-1}$ (mean $19.20 \mu \mathrm{g} \cdot \mathrm{L}^{-1}$ ). These chl- $a$ concentrations are similar to those found by [14] in the same lagoon. Values followed a significant seasonal pattern between the long dry season and the short rainy season, with higher concentrations in the long dry season (ANOVA, $p<0.05)$ and a positive correlation with temperature $(\mathrm{R}=0.372)$ and $\mathrm{pH}(\mathrm{R}=0.342)$. Higher temperatures increase primary production, which leads to higher Chl- $a$ values, $\mathrm{CO}_{2}$ consumption and consequently higher $\mathrm{pH}$. High Chl- $a$ is usually associated to eutrophication problems but even coastal lagoons subjected to pollution show lower concentrations than Peri lagoon [7] [12] [33] [34]. Coastal lagoons from the near state of Rio Grande do Sul (similar weather conditions and freshwaters) also showed lower Chl- $a$ values in spite of higher nutrients concentrations [35].

Nutrient concentrations along the sampling period are reported in Table 2 and Table 3. Dissolved nutrients showed low concentrations. Nitrite and nitrate concentrations varied from 0.6 to $7 \mu \mathrm{g} / \mathrm{L}$ and from 0.17 to $7 \mu \mathrm{g} / \mathrm{L}$ 
respectively.

Soluble reactive phosphorus $\left(\mathrm{PO}_{4}^{3-}\right)$ was significantly higher in the short rainy season (ANOVA, $p<0.05$ ) than the long dry season however the site 2 has not marked significant seasonal variation. The values ranged from 5.30 to $195.00 \mu \mathrm{g} . \mathrm{L}^{-1}$. This agrees with the finding of [22] who also studied water of this lagoon, and observed a remarkable increase in $\left(\mathrm{PO}_{4}^{3-}\right)$ during the flood period of waters $\left(186 \mu \mathrm{g} \cdot \mathrm{L}^{-1}\right)$ and very low concentrations in the long dry season under $12.5 \mu \mathrm{g} \cdot \mathrm{L}^{-1}$. Other authors have shown similar phosphorus concentrations in coastal lagoons in the world [7] [32] [36]. However, Comprida coastal lagoon in Rio de Janeiro and Peri lagoon, a subtropical coastal lagoon in Brazil state showed low concentrations $\left(<2.5 \mu \mathrm{g} \cdot \mathrm{L}^{-1}\right)$ [3] [23].

Ammonium presented also the lowest concentrations among the dissolved nutrients, but no clear pattern could be generally inferred from the data except the site 3 where the concentrations recorded in long dry season were significantly low than those recorded in the long rainy season. Seasonal means remained under $0.15 \mathrm{mg} \cdot \mathrm{L}^{-1} \mathrm{in}$ most sampled months, which is also higher when compared to data registered for other coastal lagoons (around $\left.15.0 \mu \mathrm{g} \cdot \mathrm{L}^{-1}\right)$ [3] [7] [35] [37]. Ammonium showed a strong positive correlation $(\mathrm{R}=0.338)$ with nitrite, which could be due to the fact that oxidation of ammonia results in the synthesis of nitrite.

The low dissolved nutrients concentration could be related to high recycling rates, the well oxygenated water column and high assimilation by the phytoplankton and bacterial communities, which result specially in low nitrate and soluble reactive phosphorus concentrations in the lagoon. Nutrients have strong negative correlations with in situ measured physicochemical and biological parameters which mean that these nutrients are usually brought to the water during rain events.

\section{Conclusions}

Potou lagoon showed spatial homogeneity (horizontal) despite its relative deep water column. Seasonal variations of the water quality were observed in Potou lagoon due mainly to the anthropogenic inputs to the lagoon and rainfall regimes. Physicochemical and biological parameters (temperature, salinity, $\mathrm{pH}$ ), dissolved oxygen and transparency and chlorophyll- $a$ increased during the long dry season compared to short rainy season. In contrast, an increase in nutrients (nitrite, nitrate, ammonium and soluble reactive phosphorus) was observed during the rainy periods. Thus, the precipitation received during the long and the short rainy periods, were found to have considerable impact on the coastal water characteristics at this location.

This research assumes great importance as the physicochemical and biological analysis of lagoon waters performed will assist in sustainable development and disaster management of this vulnerable yet highly resourceful area.

\section{References}

[1] Gantidis, N., Pervolarakis, M. and Fytianos, K. (2007) Assessment of the Quality Characteristics of Two Lakes (Koronia and Volvi) of N. Greece. Environmental Montitoring and Assessment, 125, 175-181. http://dx.doi.org/10.1007/s10661-006-9250-5

[2] Arain, M.B., Kazi, T.G., Jamali, M.K., Jalbani, N., Afridi, H.I. and Shah, A. (2008) Total Dissolved and Bioavailable Elements in Water and Sediment Sample and Their Accumulation in Oreochromis mossambicus of Polluted Manchar Lake. Chemosphere, 70, 1845-1856. http://dx.doi.org/10.1016/j.chemosphere.2007.08.005

[3] Bose, R., De, A., Sen, G. and Mukherjee, A.D. (2012) Comparative Study of the Physico-Chemical Parameters of the Coastal Waters in Rivers Matla and Saptamukhi: Impacts of Coastal Water Coastal Pollution. Journal of Water Chemistry and Technology, 34, 246-251. http://dx.doi.org/10.3103/S1063455X12050062

[4] Kjerve, B. (1994) Coastal Lagoons. In: Kjerfve, B., Ed., Costal Lagoon Processes, Elsevier, Amsterdam, 1-8.

[5] Esteves, F.A., Caliman, A., Santangelo, J.M., Guariento, R.D., Farjalla, V.F. and Bozelli, R.L. (2008) Neotropical Coastal Lagoons: An Appraisal of Their Biodiversity, Functioning, Threats and Conservation Management. Brazilian Journal of Biology, 68, 967-981. http://dx.doi.org/10.1590/S1519-69842008000500006

[6] Ahmed, F., Bibi, M.H., Seto, K., Ishiga, H., Fukushima, T. and Roser, B.P. (2010) Abundances, Distribution, and Sources of Trace Metals in Nakaumi-Honjo Coastal Lagoon Sediments, Japan. Environmental Monitoring and Assessment, 167, 437-491. http://dx.doi.org/10.1007/s10661-009-1065-8

[7] Gikas, G.D., Yiannakopoulou, T. and Tsihrintzis, V.A. (2006) Water Quality Trends in a Coastal Lagoon Impacted by Non-Point Source Pollution after Implementation of Protective Measures. Hydrobiologia, 563, 385-406.

http://dx.doi.org/10.1007/s10750-006-0034-2 
[8] Pereira, P., Pablo, H., Vale, C., Franco, V. and Nogueira, M. (2009) Spatial and Seasonal Variation of Water Quality in an Impacted Coastal Lagoon (Óbidos Lagoon, Portugal). Environmental Monitoring and Assessment, 153, $281-292$. http://dx.doi.org/10.1007/s10661-008-0355-X

[9] Specchiulli, A., Renzi, M., Scirocco, T., Cilenti, L., Florio, M. and Breber, P. (2010) Comparative Study Based on Sediment Characteristics and Macrobenthic Communities in Two Italian Lagoons. Environmental Monitoring and Assessment, 160, 237-256. http://dx.doi.org/10.1007/s10661-008-0691-x

[10] Piyankarage, S.C., Mallawatantri, A.P., Matsuno, Y. and Pathiratne, K.A.S. (2004) Human Impacts and the Status of Water Quality in the Bundala RAMSAR Wetland Lagoon System in Southern Sri Lanka. Wetlands Ecology Management, 12, 473-482. http://dx.doi.org/10.1007/s11273-004-6566-1

[11] Altun, O., Saçan, M.T. and Erdem, A.K. (2009) Water Quality and Heavy Metal Monitoring in Water and Sediment Samples of the Küçükçekmece Lagoon, Turkey (2002-2003). Environmental Monitoring and Assessment, 151, 345362. http://dx.doi.org/10.1007/s10661-008-0276-8

[12] Panigrahi, S., Wikner, J., Panigrahy, R.C., Satapathy, K.K. and Acharya, B.C. (2009) Variability of Nutrients and Phytoplankton Biomass in a Shallow Brackish Water Ecosystem (Chilika Lagoon, India). Limnology, 10, 73-85. http://dx.doi.org/10.1007/s10201-009-0262-z

[13] Christia, C., Papastergiadou, E., Papatheodorou, G., Geraga, M. and Papadaki, E. (2014) Seasonal and Spatial Variations of Water Quality, Substrate and Aquatic Macrophytes Based on Side Scan Sonar, in an Eastern Mediterranean Lagoon (Kaiafas, Ionian Sea). Environmental Earth Science, 71, 3543-3558. http://dx.doi.org/10.1007/s12665-013-2746-8

[14] Koné, Y.J.M. (2008) Dynamics of Carbon Dioxide and Methane in the Mangroves of Vietnam, and the Rivers and the Lagoons of Ivory Coast. Thèse de Doctorat à la Faculté des Sciencesà l’Université de Liège, Belgique, 205 p.

[15] N’Guessan, Y.A. (2008) Analyse Morphologique, sédimentologique et environnement de dépôts des sédiments superficiels des lagunes Adjin et Potou (Zone littorale de la côte d'ivoire). Thèse de Doctorat à l'UFR des Sciences de la Terre et des Ressources Minières de l’Université de Cocody à Abidjan à la Faculté, 169 p.

[16] N’Guessan, Y.A., Wognin, V., Coulibaly, A., Monde, S., Wango, T.E. and Aka, K. (2011) Analyse granulométrique et environnement de dépôts des sables superficiels de la lagune Adjin (Côte d’Ivoire). Revue Paralia, 4, 6.1-6.14. http://dx.doi.org/10.5150/revue-paralia.2011.006

[17] Traoré, A., Soro, G., Kouadio, E.K., Bamba, B.S., Oga, M.S., Soro, N. and Biemi, J. (2012) Evaluation des paramètres physiques, chimiques et bactériologiques des eaux d'une lagune tropicale en période d'étiage: La lagune Aghien (Côte d'Ivoire). International Journal of Biological and Chemical Science, 6, 7048-7058.

[18] Lorenzen, C.J. (1967) Determination of Chlorophyll and Phaeopigments: Spectrometric Equations. Limnology \& Oceanography, 12, 343-346. http://dx.doi.org/10.4319/lo.1967.12.2.0343

[19] Gantidis, N., Pervolarakis, M. and Fytianos, K. (2007) Assessment of the Quality Characteristics of Two Lakes (Koronia and Volvi) of N. Greece. Environmental Monitoring and Assessment, 125, 175-181. http://dx.doi.org/10.1007/s10661-006-9250-5

[20] Wetzel, R.G. (2001) Limnology: Lake and River Ecosystems. Academic Press, San Diego.

[21] Cardoso, L.S., Silveira, A.L.L. and Marques, D.M.L.M. (2003) Aação do vento como gestor da hidrodinâmica na lagoa Itapeva (Litoral norte do Rio Grande Sul-Brasil). Revista Brasileira de Recursos Hídricos, 8, 5-15.

[22] Koné, Y.J.M., Abril, G., Kouadio, K.N., Delille, B. and Borges, A.V. (2008) Seasonal Variability of Carbon Dioxide in the Rivers and Lagoons of Ivory Coast (West Africa). Estuaries and Coasts, 32, 246-260. http://dx.doi.org/10.1007/s12237-008-9121-0

[23] Branco, C.W.C., Esteves, F.A. and Kozlowsky-Suzuki, B. (2000) The Zooplankton and Other Limnological Features of a Humic Coastal Lagoon (Lagoa Comprida, Macaé, R.J.) in Brazil. Hydrobiologia, 437, 71-81. http://dx.doi.org/10.1023/A:1026571301811

[24] Briand, J.F., Robillot, C., Quiblier-Lloberas, C., Humbert, J.F., Coutè, A. and Bernard, C. (2002) Environmental Context of Cylindrospermopsis raciborskii (Cyanobacteria) Blooms in a Shallow Pond in France. Water Research, 36, 3183-3192. http://dx.doi.org/10.1016/S0043-1354(02)00016-7

[25] Figueredo, C.C. and Giani, A. (2009) Phytoplankton Community in the Tropical Lake of Lagoa Santa (Brazil): Conditions Favoring a Persistent Bloom of Cylindrospermopsis raciborskii. Limnologica, 39, 264-272. http://dx.doi.org/10.1016/j.limno.2009.06.009

[26] Yao, K.M. (2009) Contribution à l'étude des paramètres physico chimiques des eaux de la lagune Ebrié dans la zone d’Abidjan (Côte d'Ivoire). Thèse de Doctorat à la Faculté des Sciences à l'université de Cocody, 155 p.

[27] Panigrahi, S., Acharya, B.C., Panigrahy, R.C., Nayak, B.K., Banarjee, K. and Sarkar, S.K. (2007) Anthropogenic Impact on Water Quality of Chilika Lagoon RAMSAR Site: A Statistical Approach. Wetland Ecology Management, 15, 113-126. http://dx.doi.org/10.1007/s11273-006-9017-3 
[28] Chagas, G.G. and Suzuki, M.S. (2005) Seasonal Hydrochemical Variation in a Tropical Coastal Lagoon (Açu Lagoon, Brazil). Brazilian Journal of Biology, 65, 597-607. http://dx.doi.org/10.1590/S1519-69842005000400006

[29] Coelho, S., Gamito, S. and Pérez-Ruzafa, A. (2007) Trophic State of Foz de Almargem Coastal Lagoon (Algarve, South Portugal) Based on Water Quality and the Phytoplankton Community. Estuarine, Coastal and Shelf Science, 71, 218-231. http://dx.doi.org/10.1016/j.ecss.2006.07.017

[30] Lacerda, L.D. and Gonçalves, G.O. (2001) Mercury Distribution and Speciation in Waters of the Coastal Lagoons of Rio de Janeiro, SE Brazil. Marine Chemistry, 76, 47-58. http://dx.doi.org/10.1016/S0304-4203(01)00046-9

[31] Maced, M.F., Duarte, R., Mendes, R. and Ferreira, J.G. (2001) Annual Variation of Environmental Variables, Phytoplankton Species Composition and Photosynthetic Parameters in a Coastal Lagoon. Journal of Plankton Research, 23, 719-732. http://dx.doi.org/10.1093/plankt/23.7.719

[32] Pereira, A.A., van Hattum, B., Brouwer, A., van Bodegom, P.M., Rezende, C.E. and Salomons, W. (2006) Effects of Iron-Ore Mining and Processing on Metal Bioavailability in a Tropical Coastal Lagoon. Journal of Soils and Sediments, 8, 239-252. http://dx.doi.org/10.1007/s11368-008-0017-1

[33] Esteves, F.A., Ishii, I.H. and Camargo, A.F.M. (1984) Pesquisas limnológicas em 14 lagoas do litoral do Estado do Rio de Janeiro. In: Lacerda, L.D., Araújo, D.S.D., Cerqueira, R. and Turcq, B., Eds., Restingas: Origem, estrutura, processos, CEUFF, Niterói, 443-454.

[34] Lloret, J., Marín, A. and Marín-Guirao, L. (2008) Is Coastal Lagoon Eutrophication Likely to Be Aggravated by Global Climate Change? Estuarine, Coastal and Shelf Science, 78, 403-412. http://dx.doi.org/10.1016/j.ecss.2008.01.003

[35] Pedrozo, C.S. and Rocha, O. (2006) Zooplankton and Water Quality of Lakes of the Northern Coast of Rio Grande do Sul State, Brazil. Acta Limnologica Brasiliensia, 17, 445-464.

[36] Phlips, E.J., Badylak, S. and Grosskopf, T. (2002) Factors Affecting the Abundance of Phytoplankton in a Restricted Subtropical Lagoon, the Indian River Lagoon, Florida, USA. Estuarine, Coastal and Shelf Science, 55, 385-402. http://dx.doi.org/10.1006/ecss.2001.0912

[37] González, F.U.T., Herrera-Silveira, J.A. and Aguirre-Macedo, M.L. (2008) Water Quality Variability and Eutrophic Trends in Karstic Tropical Coastal Lagoons of the Yucatán Peninsula. Estuarine, Coastal and Shelf Science, 76, 418430. http://dx.doi.org/10.1016/j.ecss.2007.07.025 